\title{
THE 50 MOST CITED ARTICLES IN THE BRAZILIAN MEDICAL LITERATURE ON KNEE SURGERY
}

\author{
OS 50 ARTIGOS MAIS CITADOS DA LITERATURA \\ MÉDICA BRASILEIRA SOBRE CIRURGIA DO JOELHO
}

\author{
Renan Vinicius Romano Martinelli ${ }^{1}$ (1), Diego Costa Astur ${ }^{1}$ (i), Gustavo Kenzo Miyashita ${ }^{1}$ (D), João Victor Novaretti ${ }^{1}$ (i), \\ MOISÉS COHEN ${ }^{1}$ (1), ALEXANDRE PEDRO NICOLINI ${ }^{1}$ (i)
}

1. Universidade Federal de São Paulo, Department of Orthopedics and Traumatology, São Paulo, SP, Brazil.

\section{ABSTRACT}

Objective: To provide an analysis of the 50 most cited articles on knee surgery in the Brazilian medical literature. Methods: This is a study of systematic review and meta-analysis, level of evidence 3. It was carried out through search in the SCOPUS database to identify scientific articles published in the Brazilian medical literature. Eighty-six Brazilian journals were analyzed, and articles with ten or more citations and which had the word "joelho" or "knee" in the title, abstract or keywords were selected. Results: All articles were published as of the year 2000 in 14 journals. The Journal Clinics presented the largest number of publications, followed by Acta Ortopédica Brasileira. The main focus of the studies was on anatomy and biomechanics, mainly from Brazilian authors. Most of the authors were Brazilian, from Brazilian and public research institutions. Conclusion: Biometric analysis has been gaining ground in recent years, but its interpretation must consider various aspects related to the paramount analytical importance.

Keywords: Knee. Systematic Review. Data base.

\section{RESUMO}

Objetivo: Fornecer uma análise dos cinquenta artigos mais citados sobre cirurgia do joelho na literatura médica brasileira. Métodos: Foi utilizada a base de dados da SCOPUS para identificar artigos científicos publicados na literatura médica brasileira de 1945 a junho de 2008 com o tema referente ao joelho. Foram analisados 86 periódicos brasileiros e selecionados os artigos com número de citações igual ou superior a dez que possuíam a palavra "joelho" ou knee no título, resumo ou palavras-chave. Foram selecionados aqueles que possuíam a articulação do joelho como foco principal do estudo, chegando ao resultado final de cinquenta artigos mais citados. Resultados: Todos os artigos foram publicados a partir do ano 2000, em quatorze revistas. A Revista Clinics apresentou maior número de publicações, seguida da Acta Ortopédica Brasileira. A maior parte foi sobre estudos sobre anatomia e biomecânica, preponderamente de autores brasileiros. Instituições de pesquisa brasileiras e públicas foram as responsáveis pela maior parte das pesquisas. Conclusão: Análise biométrica vem ganhando espaço nos últimos anos, contudo sua interpretação deve considerar variados aspectos relacionados a importância analítica.

Descritores: Joelho. Revisão Sistemática. Bases de Dados.

Citation: Martinelli RVR, Astur DC, Miyashita GK, Novaretti JV, Cohen M, Nicolini AP. The 50 most cited articles in the brazilian medical literature on knee surgery. Acta Ortop Bras. [online]. 2020;28(1):44-8. Available from URL: http://www.scielo.br/aob.

\section{INTRODUCTION}

The knee joint is an area of wide interest in medicine, and the subject of intense debate among specialists in Orthopedics and Trauma. Since the first attempts of surgically treating osteoarthritis more than a century and a half ago, the interest in knee surgery has arisen enormously, particularly with milestones in the treatment of degenerative diseases and the introduction of arthroscopic and joint preservation surgery, ${ }^{1}$ making this articulation the focus of many human body scientific studies.

Society's growing demand and requirement for results that keep getting closer to perfection, coupled with technological innovations, have helped to drive a greater quest for knowledge. Researchers' personal ambitions also contribute to the exponential increase of scientific studies in various areas of interest, especially in the medical literature, where authors combine the satisfaction of new discoveries with the increasing demand for scientific publications by universities, employers and societies. ${ }^{2}$ Thus, countless researches have emerged in the last decades, contributing to a better understanding of knee aspects, especially in relation to anatomy, biomechanics, treatment, surgical techniques and rehabilitation, among others. ${ }^{3}$

In view of this growth in the academic area, the researchers needed methods to efficiently track the most impacting advances and identify the existing challenges. Bibliometric science can accomplish this goal, ${ }^{4,5}$ since it can provide qualitative and quantitative publications analysis, as well as their characteristics, thus providing their academic impact within a field of research. ${ }^{3}$

All authors declare no potential conflict of interest related to this article.

Study was conducted at the Universidade Federal de São Paulo, Department of Orthopedics and Traumatology, São Paulo, SP, Brazil.

Correspondence: Renan Vinicius Romano Martinelli. Avenida Onze de Junho, 970, Vila Clementino, São Paulo, SP, Brazil. 04041-003. renanmartinelli08@gmail.com 
Bibliometric studies fall into the category of systematic reviews, representing an instantaneous analysis that provides a cross-sectional view of the current state of the object studied. They have a limited half-life due to being part of a continuous process in which high quality impact articles are constantly produced. ${ }^{3}$

A useful method for determining the impact of an article on the scientific community is by performing a citation analysis. Each article that is referenced by another scientific article is credited as a "citation." This form of analysis is an important method to determine the influence of an article on scientific progress, as well as to evaluate the Impact Factor (IF) of a scientific journal. ${ }^{7}$ The study of citation analysis can help identify articles, research topics, and authors of influence. ${ }^{8}$ In the field of international research, several analyses were done to identify the most cited articles about different themes, such as: epilepsy, ${ }^{9}$ encephalic brain trauma ${ }^{10}$, orthodontics, ${ }^{11}$ radiology, ${ }^{12}$ surgery ${ }^{13}$ and orthopedics ${ }^{3}$, among others. However, we need to collect bibliometric data in the context of the Brazilian national literature.

The objective of this study is to provide an analysis of the 50 most cited articles of the Brazilian medical literature on knee surgery, allowing a more accurate comprehension of the qualities of the citation classics, as well as highlighting the main intellectual research marks in this field in Brazil.

\section{MATERIALS AND METHODS}

This is a systematic, quantitative, observational and analytical cross-sectional review study. Articles were identified by a bibliometric analysis in July 2018 using SCOPUS database search tools. We chose this index because it contains the largest number of Brazilian journals. We selected 86 journals with affiliation to Brazil with "area of interest in medicine" (Table 1 and Figure 1), obtained from official information from SCOPUS. The study population consisted of a sample of scientific articles published in the Brazilian medical literature from 1946 to June 2018, regardless of the language. Each of these journals was individually examined, and the articles analyzed according to the flowchart presented below (Figure 1). Initially, the articles were arranged in descending order of citation and the ones with ten or more citations were selected. From this selection, a new search was performed with the identification of all articles that presented the word "joelho" or "knee" in the title, abstract or keywords, excluding those that did not refer to the knee joint. They were arranged in alphabetical order (Table 2) to identify duplicates and later analyzed by two independent observers who, reading the abstract, selected the articles that presented the knee as the main focus of the study. In cases of divergence in the selection process, the analysis was submitted to a third observer. This new sample was placed in the descending order, according to the number of citations

Table 1. List of journals of the Brazilian medical literature with area of interest in "Medicine" searched in the SCOPUS database.

Journals

\begin{tabular}{|c|c|c|}
\hline Acta Cirurgica Brasileira & Jornal Brasileiro de Nefrologia & Revista Brasileira de Medicina do Trabalho \\
\hline Acta Ortopedica Brasileira & Jornal Brasileiro de Patologia e Medicina Laboratorial & Revista Brasileira de Neurologia e Psiquiatria \\
\hline Acta Scientiarum - Health Sciences & Jornal Brasileiro de Pneumologia & Revista Brasileira de Oftalmologia \\
\hline Adolescencia e Saude & Jornal Brasileiro de Psiquiatria & Revista Brasileira de Ortopedia \\
\hline Agora & Jornal Brasileiro de Reproducao Assistida & Revista Brasileira de Otorrinolaringologia \\
\hline Anais Brasileiros de Dermatologia & Jornal de Pediatria & Revista Brasileira de Plantas Medicinais \\
\hline Archives of endocrinology and metabolism & Jornal Vascular Brasileiro & Revista Brasileira de Psiquiatria \\
\hline Arquivos Brasileiros de Cardiologia & Journal of Coloproctology & Revista Brasileira de Reumatologia \\
\hline $\begin{array}{c}\text { Arquivos brasileiros de cirurgia digestiva: } \\
A B C D=\text { Brazilian archives of digestive surgery }\end{array}$ & Journal of Morphological Sciences & Revista Brasileira de Saude Materno Infantil \\
\hline Arquivos Brasileiros de Oftalmologia & Journal of Physical Education (Maringa) & Revista Brasileira de Terapia Intensiva \\
\hline Arquivos de Gastroenterologia & Medicina (Brazil) & Revista da Associacao Medica Brasileira \\
\hline Arquivos de Neuro-Psiquiatria & Memorias do Instituto Oswaldo Cruz & Revista da Sociedade Brasileira de Medicina Tropical \\
\hline Brazilian journal of Anesthesiology (Elsevier) & Motriz. Revista de Educacao Fisica & Revista de Nutricao \\
\hline Brazilian Journal of Cardiovascular Surgery & O Mundo da Saude & Revista de Psiquiatria Clinica \\
\hline Brazilian Journal of Infectious Diseases & $\begin{array}{c}\text { Pesquisa Brasileira em Odontopediatria } \\
\text { e Clinica Integrada }\end{array}$ & Revista de Saude Publica \\
\hline Brazilian Journal of Medical and Biological Research & Pesquisa Odontologica Brasileira = Brazilian oral research & Revista do Colegio Brasileiro de Cirurgioes \\
\hline Brazilian Journal of Physical Therapy & Physis (Rio de Janeiro, Brazil) & Revista do Instituto de Medicina Tropical de Sao Paulo \\
\hline Cadernos de Saude Publica & Psiquiatria Biologica & Revista Gaucha de Enfermagem / EENFUFRGS \\
\hline Ciencia e Saude Coletiva & Radiologia Brasileira & Revista Latinoamericana de Psicopatologia Fundamental \\
\hline Clinics & Revista Ambiente e Agua & Revista Paulista de Pediatria \\
\hline CoDAS & Revista Brasileira de Anestesiologia & Sao Paulo Medical Journal \\
\hline Coluna/ Columna & Revista Brasileira de Cardiologia Invasiva & Saude e Sociedade \\
\hline Dementia e Neuropsychologia & $\begin{array}{c}\text { Revista Brasileira de Cineantropometria } \\
\text { e Desempenho Humano }\end{array}$ & Scientia Medica \\
\hline Einstein (São Paulo, Brazil) & Revista Brasileira de Enfermagem & Sleep Science \\
\hline GED - Gastrenterologia Endoscopia Digestiva & Revista Brasileira de Epidemiologia & Surgical and Cosmetic Dermatology \\
\hline Genetics and Molecular Research & Revista Brasileira de Ginecologia e Obstetricía & Tempo Psicanalitico \\
\hline Historia, Ciencias, Saude - Manguinhos & Revista Brasileira de Hematologia e Hemoterapia & Trends in Psychiatry and Psychotherapy \\
\hline International Braz J Urol & Revista Brasileira de Medicina & \\
\hline International Journal of High Dilution Research & Revista Brasileira de Medicina do Esporte & \\
\hline
\end{tabular}




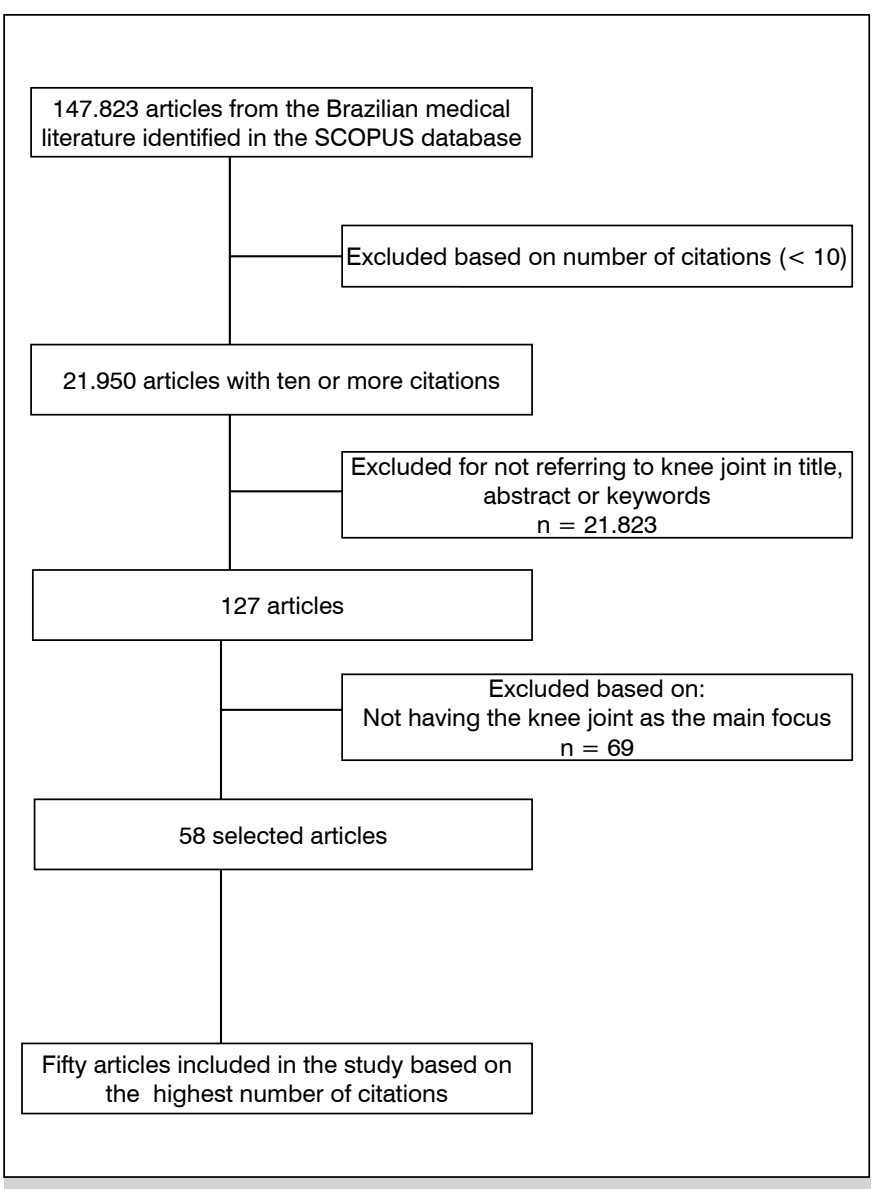

Figure 1. Flowchart.

and the first fifty were selected (Table 2). All authors of this research signed the Informed Consent Form and the work was submitted to the Ethics and Research Committee of Unifesp - Hospital São Paulo.

\section{RESULTS}

Each of these articles was analyzed individually according to the authors' most relevant information, such as academic affiliation of the main author, year of publication, main focus of the study, number of citations, and the journal of publication.

Among the 89 journals, Clinics was the main medium of publication, being responsible for 19 indexes from different studies, followed by Acta Ortopédica Brasileira with 7.

The main focus varied considerably among all the fields of research, with a higher prevalence on anatomy and biomechanics, totaling 11 articles, followed by biomolecular studies (9) and studies on prevention and rehabilitation (8).

Although we identified a total of 211 different authors, only twenty of them were published more than once. In the specific analysis about the first author, only four were published at least twice from a total of 46 different first authors, all Brazilian.

Finally, we analyzed the institutions related to the articles considering only the first author's academic affiliation. The Universidade de São Paulo (USP), with 18 articles, stood out as the most predominant, followed by the Universidade Federal de São Paulo (Unifesp), with 8 articles.

\section{DISCUSSION}

The amount of citations has become an important instrument for the assessment of an article and, besides being valuable to measure its own impact in the academic context, it also contributes to the analysis of the publication vehicle and of its authors. However, its data should not be analyzed in isolation and the social and temporal context in which it is inserted should be considered.

In this study, it is important to highlight that all the fifty most cited articles were published after the year 2000, which lets us infer that studies with higher quality and importance began to arise from then on. This was the moment of intense global technological transformations, with changes in the form of communication, driven by the spread of ever faster and more effective communication networks, such as the internet. This event contributed to the greater access to knowledge, reflecting the increase of research done in the scientific world. This pattern of publication dates found in our study resembles the findings of the international literature, except for the so-called "classic articles" that correspond to the ones that became important milestones in the medical literature on the subject studied, which have had a fundamental relevance since its production, being more present in international studies than in our country.

Although there are a large number of different authors, totaling 211, it is noted that only twenty of them $(9.47 \%)$ were present in more than one occasion, which may indicate difficulties on the part of Brazilian authors in the production of works or, more likely, they have directly chosen to publish in international journals. Thus their research is not found in the national literature.

All articles were present in 14 of the 86 journals surveyed (16.27\%), reflecting the greater searching tendency, with a specific focus on surgical, genetic and musculoskeletal system subjects. Although not only linked to orthopedics and traumatology, the journal Clinics was predominant in this study, which shows its high capacity of scientific production in the national territory, occupying the fourth position in the biometric analysis of citations in the CiteScore ranking. Acta Ortopédica Brasileira appears as the second most prevalent in publications, possibly because it is specifically devoted to studies with an interest in orthopedics and traumatology.

Interestingly, 34 articles (68\%) are from research institutions located in the state of São Paulo, highlighting their academic importance in the national territory. USP and Unifesp, both public educational institutions, stood out as the most prevalent academic institution. All three articles published in the journal Genetics and Molecular Research had as their main focus the study classified as "biomolecular" and, differently from the pattern found in this study, there were no Brazilian first authors, two of them were Chinese and one was Thai. Although they are all foreigners, the superficial analysis may bring misinterpretations. In recent years studies of this nature have been widely developed all over the world, due to the interest in new discoveries abounding intensively, even in Brazil, although through eventual investment restrictions that we face constantly. The absence of articles by Brazilian authors with this focus leads us to infer that such articles are probably intended for publication in the international literature, rather than their nonexistence.

Still under this perspective, it is possible to observe that all foreign works were published after 2011 and focused almost exclusively on biomolecular research. These data suggest that researchers from other countries find opportunities in Brazil for publication that they sometimes do not find around the world, either because our journals actually have academic value or because they simply did not find space in international journals, which are very demanding.

\section{CONCLUSION}

We conclude that the biometric analysis has been gaining ground in recent years, as a means of evaluating scientific studies; however, this study did not aim to analyze the quality of articles and first authors, since many relevant articles are probably published in the international literature, an issue not addressed by this study. 
Table 2. List of the 50 most cited articles.

\begin{tabular}{|c|c|}
\hline List of the most cited articles & Citations \\
\hline Questionário específico para sintomas do joelho Lysholm Knee Scoring Scale - tradução e validação para a língua portuguesa & 42 \\
\hline Changes in joint kinematics in children with cerebral palsy while walking with and without a floor reaction ankle-foot orthosis & 40 \\
\hline Tradução e Validação Cultural do Questionário Algofuncional de Lequesne para Osteoartrite de Joelhos e Quadris para a Língua Portuguesa & 40 \\
\hline Isokinetic assessment of the hip muscles in patients with osteoarthritis of the knee & 34 \\
\hline Metric measurements and attachment levels of the medial patellofemoral ligament & 33 \\
\hline Comparison of two methods of femoral tunnel preparation in single-bundle anterior cruciate ligament reconstruction. A prospective randomized study & 21 \\
\hline Diacerhein versus glucosamine in a rat model of osteoarthritis & 20 \\
\hline Epidemiological study on tibial plateau fractures at a level i trauma center & 20 \\
\hline Anserine syndrome & 19 \\
\hline Avaliação do ligamento anterolateral do joelho por meio de exame de ressonância magnética & 19 \\
\hline Electromyographic activity evaluation of the patella muscles during squat isometric exercise in individuals with patellofemoral pain syndrome & 19 \\
\hline Anterior cruciate ligament reconstruction with double bundle versus single bundle & 18 \\
\hline Muscle strength and exercise intensity adaptation to resistance training in older women with knee osteoarthritis and total knee arthroplasty & 18 \\
\hline The influence of tourniquet use and operative time on the incidence of deep vein thrombosis in total knee arthroplasty & 17 \\
\hline Association of the IL-6 -174G/C gene polymorphism with knee osteoarthritis in a Thai population & 16 \\
\hline Biomechanical and histological evaluation of hydrogel implants in articular cartilage & 16 \\
\hline Efeito de exercícios terapêuticos no equilíbrio de mulheres com osteoartrite de joelho Uma revisão sistematica & 16 \\
\hline Manual for guided home exercises for osteoarthritis of the knee & 16 \\
\hline Study of human acellular amniotic membrane loading bone marrow mesenchymal stem cells in repair of articular cartilage defect in rabbits & 16 \\
\hline The effects of stretching on the flexibility, muscle performance and functionality of institutionalized older women & 16 \\
\hline Anatomical study on the anterolateral ligament of the knee & 15 \\
\hline Isokinetic dynamometry in elderly women undergoing total knee arthroplasty & 15 \\
\hline Positioning of the femoral tunnel for arthroscopic reconstruction of the anterior cruciate ligament & 15 \\
\hline Qualidade de vida após artroplastia total do joelho/ revisão sistemática & 15 \\
\hline An in vitro biomechanical comparison of anterior cruciate ligament reconstruction Single bundle versus anatomical double bundle techniques & 14 \\
\hline Current concepts in osteoarthritis & 14 \\
\hline Effectiveness of radiation synovectomy with samarium 153 particulate hydroxyapatite in rheumatoid arthritis patients with knee synovitis & 14 \\
\hline Influence of patellofemoral pain syndrome on plantar pressure in the foot rollover process during gait & 14 \\
\hline Knee extensor torque of men with early degrees of Osteoarthritis is associated with pain, stiffness and function & 13 \\
\hline Oral administration of curcumin (Curcuma longa) can attenuate the neutrophil inflammatory response in zymosan-induced arthritis in rats & 13 \\
\hline Avaliação muscular isocinética da articulação do joelho em atletas das seleções brasileiras infanto e juvenil de voleibol masculino & 12 \\
\hline Comparative study on anterior cruciate ligament reconstruction Determination of isometric points with and without navigation & 12 \\
\hline Correlation between magnetic resonance imaging and physical exam in assessment of injuries to posterolateral corner of the knee & 12 \\
\hline Economic impact of treatment for surgical site infections in cases of total knee arthroplasty in a tertiary public hospital in Brazil & 12 \\
\hline Efetividade da estimulação elétrica na reabilitação pós-lesões ligamentares e meniscais/ Uma revisão sistemática & 12 \\
\hline Eficacia Analgésica do Uso de Dose Alta de Morfina Intra articular em Pacientes Submetidos a Artroplastia Total de Joelho & 12 \\
\hline Isokinetic Evaluation of Knee Extensor and Flexor Muscles in Professional Soccer Players & 12 \\
\hline Translation and validation of the knee society score - KSS for Brazilian Portuguese & 12 \\
\hline Análise biomecânica das articulações do quadril e joelho durante a marcha em participantes idosos & 11 \\
\hline Early osteoarthritis and reduced quality of life after retirement in former professional soccer players & 11 \\
\hline Energy expenditure during cane assisted gait in patients with knee osteoarthritis & 11 \\
\hline Implantation of platelet-rich fibrin and cartilage granules facilitates cartilage repair in the injured rabbit knee Preliminary report & 11 \\
\hline Increased serum ADAMTS 4 in knee osteoarthritis A potential indicator for the diagnosis of osteoarthritis in early stages & 11 \\
\hline Isokinetic torque peak and hamstrings quadriceps ratios in endurance athletes with anterior cruciate ligament laxity & 11 \\
\hline Knee joint dysfunctions that influence gait in cerebrovascular injury & 11 \\
\hline Knee pain and associated occupational factors & 11 \\
\hline Measurement of tibial slope angle after medial opening wedge high tibial osteotomy/ Case series & 11 \\
\hline Physical activity and its association with quality of life in patients with osteoarthritis & 11 \\
\hline Protective effects of tumor necrosis factor- $\alpha$ blockade by adalimumab on articular cartilage and subchondral bone in a rat model of osteoarthritis & 11 \\
\hline Treatment of infections following total knee arthroplasty 2 Year follow up outcomes & 11 \\
\hline
\end{tabular}

Publication year 2018 
AUTHORS' CONTRIBUTIONS: Each author contributed individually and significantly to the development of this article. RVRM: writing of the article, review and preparation of the entire research project. DCA: writing of the article, review and preparation of the entire research project. JVN: writing of the article, review and preparation of the entire research project. GKM. MC: preparation of the entire research project and text review. APN: writing of the article and text review.

\section{REFERENCES}

1. Gordon-Taylor G. Sir William Fergusson, 1808-1877. Med Hist. 1961;5:1-14

2. Garfield E. To cite or not to cite: a note of annoyance. Curr Comment. 1977;(35):5-8

3. Kelly J, Glynn R, O'Briain D, Felle P, McCabe JP. The 100 classic papers of orthopaedic surgery: a bibliometric analysis. J Bone Joint Surg Br. 2010;92(10):1338-43.

4. Benton DC. Using bibliometrics to support revalidation requirements. Nurs Stand. 2017;32(1):44-51.

5. Moed HF. The impact-factors debate: the ISI's uses and limits. Nature. 2002;415(6873):731-2.

6. Wu JJ, Choi YM, Marczynski W. The 100 most cited psoriasis articles in clinica dermatologic journals, 1970 to 2012. J Clin Aesthet Dermatol. 2014;7(10):10-9.

7. Moed HF. New developments in the use of citation analysis in research evaluation. Arch Immunol Ther Exp. 2009;57(1):138
8. Smith DR, Rivett DA. Bibliometrics, impact factors and manual therapy: balancing the science and the art. Man Ther. 2009;14:456-9.

9. Ibrahim GM, Snead III OC, Rutka JT, Lozano AM. The most cited works in epilepsy: trends in the "citation classics". Epilepsia. 2012;53(5):765-70.

10. Dolan RS, Hanna TN, Warraich GJ, Johnson JO, Khosa F. The top 100 articles in the radiology of trauma: a bibliometric analysis. Emerg Radiol. 2015;22(6):667-75.

11. Lee S, Shin J, Haro M, Khair M, Riboh JC, Kuhns BD, et al. Fifty most cited articles for femoroacetabular impingement and hip arthroscopy. Front Surg. 2015;2:41.

12. Pagni M, Khan NR, Cohen HL, Choudhri AF. Highly cited works in radiology: the top 100 cited articles in radiologic journals. Acad Radiol. 2014;21(8):1056-66.

13. Long X, Huang JZ, Ho YS. A historical review of classic articles in surgery field. Am J Surg. 2014;208(5):841-9. 